\title{
Development and evaluation of petrol operated digger for subsoil fertilizer application for horticulture crops
}

\section{S.L. RATHOD AND D.J. SHRINIVASA}

Received : 25.07.2017; Revised : 28.08.2017; Accepted : 14.09.2017

See end of the Paper for authors' affiliation

Correspondence to :

\section{S.L. RATHOD}

Padmashree Dr. D.Y.Patil College of Agricultural

Engineering, Talsande, KOLHAPUR (M.S.) INDIA Email : shriniv70@gmail. com
- ABSTRACT : Farming is an important feature of our way of life. The challenge for agriculture over the coming decades will be to meet the world's increasing demand for food in a sustainable way. As long as agriculture remains a soil-based industry, major increases in productivity are unlikely to be attained without ensuring that plants have an adequate and balanced supply of nutrients. To achieve healthy growth and optimal yield levels, nutrients must be available not only in the correct quantity and proportion, but also in usable form at the right place in the soil. Hence, subsurface application of fertilizers at varying depth is the need of time so that nutrients will be placed at the different depth in subsoil to provide adequate amounts of minerals at the different growth stage of the plant, therefore, problem of leaching is avoided. Hence, a mechanical digger (petrol operated) was developed and evaluated under coconut, banana and sapota plants for subsoil fertilizer application. The results obtained were digging capacity at 25 to $30 \mathrm{~cm}$ depth, minimum fuel consumption and digging cost incurred were 450 holes/h, $0.520 \mathrm{l} / \mathrm{h}$ and Rs. 105/h, respectively.

- KEY WORDS : Digger, Digging, Fertilizer application, Subsoil application

- HOW TO CITE THIS PAPER : Rathod, S.L. and Shrinivasa, D.J. (2017). Development and evaluation of petrol operated digger for subsoil fertilizer application for horticulture crops. Internat. J. Agric. Engg., 10(2) : 564-569, DOI: 10.15740/HAS/IJAE/10.2/564-569. 